\title{
Thermo-economic optimization of a hybrid solar district heating plant with flat plate
} collectors and parabolic trough collectors in series

Tian, Zhiyong; Perers, Bengt; Furbo, Simon; Fan, Jianhua

Published in:

Energy Conversion and Management

Link to article, DOI:

10.1016/j.enconman.2018.03.034

Publication date:

2018

Document Version

Peer reviewed version

Link back to DTU Orbit

Citation $(A P A)$ :

Tian, Z., Perers, B., Furbo, S., \& Fan, J. (2018). Thermo-economic optimization of a hybrid solar district heating plant with flat plate collectors and parabolic trough collectors in series. Energy Conversion and Management, 165, 92-101. https://doi.org/10.1016/j.enconman.2018.03.034

\section{General rights}

Copyright and moral rights for the publications made accessible in the public portal are retained by the authors and/or other copyright owners and it is a condition of accessing publications that users recognise and abide by the legal requirements associated with these rights.

- Users may download and print one copy of any publication from the public portal for the purpose of private study or research.

- You may not further distribute the material or use it for any profit-making activity or commercial gain

- You may freely distribute the URL identifying the publication in the public portal 
Thermo-economic optimization of a hybrid solar district heating plant with flat plate

collectors and parabolic trough collectors in series

Zhiyong Tian, Bengt Perers, Simon Furbo, Jianhua Fan

Department of Civil Engineering, Technical University of Denmark, Brovej Building 118, Lyngby, 2800,

Denmark

\begin{abstract}
Large-scale solar heating plants for district heating networks have gained great success in Europe, particularly in Denmark. A hybrid solar district heating plant with $5960 \mathrm{~m}^{2}$ flat plate collectors and $4039 \mathrm{~m}^{2}$ parabolic trough collectors in series was built in Taars, Denmark in 2015. The solar heating plant was used as a reference case in this study. A validated TRNSYS-GenOpt model was set up to optimize the key design parameters of the plant, including areas of both collector types, storage size, orientation of the parabolic trough collectors and so on. This study introduces a generic method to optimize the hybrid solar district heating systems based on levelized cost of heat. It is found that the lowest net levelized cost of heat of hybrid solar heating plants is $0.367 \mathrm{DKK} / \mathrm{kWh}$. The system levelized cost of heat can be reduced by $5 \%-9 \%$ by use of solar collectors in the district heating network. The results also show that parabolic trough collectors are economically feasible for district heating networks in Denmark. The generic and multivariable levelized cost of heat method can guide engineers and designers on the design, construction and control of large-scale solar heating plants.
\end{abstract}

\title{
Keywords
}

Hybrid solar district heating plants; LCOH optimization; Parabolic trough collector; Flat plate collector; TRNSYS-GenOpt. 


\section{Introduction}

Solar energy is widely used in the building sector to supply space heating and cooling. Rad et al. [1] reviewed solar community heating and cooling systems with borehole thermal energy storage and gave suggestions about the development of borehole storage. Hazami et al. [2] simulated two domestic hot water systems with flat plate collectors and evacuated tube collectors separately and compared two systems by means of TRNSYS. Deng et al. [3] investigated a solar space heating system coupled with air source heat pump in TRNSYS. Kemal et al. [4] revealed the influence of the size of the storage tank on the performance and usability of solar water heating systems. Kaçan et al. [5] found that the actual optimum values for independent parameters have a vital importance for design engineer with respect to select the proper system component for solar heating system. Li et al. [6] discussed the operational strategy of a combined solar and ground source heat pump system for an office building in TRNSYS. Bellos et al. [7] did energetic and financial evaluation of solar assisted heat pump space heating systems with TRNSYS. Pardo García et al. [8] studied district heating configurations with photovoltaic thermal hybrid solar collectors for a central European multi-family house. Ramos et al. [9] also used TRNSYS to study a combined heating, cooling and power provision in the urban environment. Bava et al. [10] developed a numerical model to investigate the flow distribution in different operation conditions for solar district heating plants in Denmark. Bava et al. [11] also investigated pressure drop and flow distribution in a solar collector with horizontal U-connected pipes with this numerical model. Bava et al. [12] developed a detailed TRNSYS-Matlab model to simulate the thermal performance of large solar collector fields for district heating applications based on developed numerical model. Wang et al. [13] carried out energy, exergy and environmental analysis of a hybrid combined cooling heating and power system utilizing biomass and solar energy. The vision of the Solar Heating and Cooling Programme of the International Energy Agency is "By 2050 a worldwide capacity of 5 $\mathrm{kW}_{\text {th }}$ per capita of solar thermal energy systems is installed and significant reductions in energy consumption are achieved by using passive solar and daylighting: thus solar thermal energy meeting 50\% of low temperature heating and cooling demand (heat up to $250{ }^{\circ} \mathrm{C}$ )" [14]. Large-scale solar heating plants for 
district heating networks have developed fast in the last decades, and are one of the most successful applications of solar energy for the building sector.

\subsection{Solar district heating plants}

In the northern European countries, district heating networks have supplied both space heating and domestic hot water to many residents for many years. In the early 1980s, several large solar heating plants were installed in Sweden, which is the first country to apply large solar collector arrays into district heating networks [15]. Recently, the number of large solar district heating plants has increased very fast in Denmark, Germany and Austria [16]. Fisch et al. [17] reviewed all the large-scale solar heating plants in Europe in 1998. IEA-SHC Task 9, 45 and 55 have focused on the application of large solar heating plants in district heating networks [14].

De Guadalfajara et al. [18] evaluated the potential of large solar heating systems with seasonal storage for 5 typical climate conditions in Spain. The system included a $2854 \mathrm{~m}^{2}$ solar collector field. It was found that the estimated cost of the heat produced in large solar heating systems with seasonal storage with a solar fraction of 50\% can be competitive with the heat cost of traditional domestic heat boilers in Spain. Bauer et al. [19] reviewed central solar heating plants with seasonal heat storage in Germany. Experiences from construction and operation of the research and pilot plants has led to technical improvement, higher efficiencies and cost reduction. Olsthoorn et al. [20] reviewed optimization methods on integration of renewable energy into district heating. The optimization method consists of a multi-objective method, sensitivity analysis, thermodynamic-economic analysis, and genetic algorithm. Tulus et al. [21] did multiobjective optimizations on central solar heating plants with seasonal storage in Spain. The results showed that central solar heating plants with seasonal storage led to significant environmental and economic improvements compared to the use of conventional natural gas heating systems. Life cycle assessment for economy and environment was carried out to optimize central solar heating plants. Guerreiro et al. [22] carried out the investigations on efficiency improvement and potential levelized cost of energy reduction with a linear Fresnel concentrator plant with storage. LCOEs showed that there was an enormous potential for the investigated plant. Sartor et al. [23] did simulations and optimizations of a CHP biomass plant and 
district heating network. The contribution presented a synthetic way to achieve such a task using only simple models on thermodynamic, combustion process, heat transfer and finance. The solar district heating system combined with borehole thermal energy storage (BTES) in Drake Landing Solar Community in Canada has managed to provide $96 \%$ of the community's annual space heating demand with solar heat for the period 2012-2016 [24].

Large solar district heating plants have gained great success in Denmark recently [25]. More than 1.3 million $\mathrm{m}^{2}$ collectors are in operation in solar heating plants in Denmark by the end of 2016 [26]. Flat plate collectors have been used in the large-scale solar district heating plants in Denmark. Flat plate collectors have a bit lower efficiency at high temperature levels compared to evacuated tube collectors [27], Fresnel collectors and parabolic trough collectors [28]. Parabolic trough collectors are the more cost-effective at high temperature ranges such as $80-200^{\circ} \mathrm{C}$ during these collectors [28]. Parabolic trough collectors are mainly used for solar power plants with oil or molten salt as heat transfer fluid. Parabolic trough collector with water as heat transfer fluid for direct steam generation also is an attractive option in electricity generation or industrial process [29]. Leiva-Illanes et al. [30] analyzed a solar poly-generation plant with parabolic trough collectors for electricity, water, cooling and heating in high direct normal irradiation conditions. More and more small-scale parabolic trough collectors are optimized to supply heat to industrial process [31] and hot water production. A preliminary case study of parabolic trough collectors for district heating networks at high latitudes with low solar radiation resources was first carried out in 2000 [32]. The economic comparison indicated that parabolic trough collector systems could be competitive with flat plate collectors. But few practical projects with parabolic trough collectors for district heating are found during the last decades. The Danish company Aalborg CSP A/S [33] and Technical University of Denmark (DTU) [34] started in 2013 to investigate the feasibility of parabolic trough collectors for district heating networks in large solar heating plants supported by the Danish Energy Agency through the Energy Technology Development and Demonstration Program (EUDP). A hybrid solar heating field with both flat plate collectors and parabolic trough collectors in series has been constructed and connected to the existing district heating network in Taars [35]. It was found that the flat plate collector field was oversized. To avoid too high temperature in the 
system, the parabolic trough collectors therefore was often defocused in the summer [36]. This reduces the cost efficiency of the plant dramatically. All the potential benefits of the hybrid plant can only be experienced if the design, size and operation of the whole integrated system is consistently optimized [37]. The optimization of such hybrid solar district heating plants with different solar collector technologies is a major issue for large solar heating plants.

\subsection{Levelized cost of heat}

Designing solar heating plants is a multivariable optimization task because many design parameters should be varied and optimized on a project-specific basis, especially the area of the collectors and storage size. Cost of application of solar energy systems in district heating networks has been discussed for a long time. The levelized cost of energy (LCOE) has become the most popular and common criteria to identify the most cost-effective energy production technologies on a consistent basis [38]. The LCOE not only considers the cost of the energy systems, but also depends on the energy production of the investigated system simultaneously. Levelized cost of heat $(\mathrm{LCOH})$, derived from LCOE, is used to evaluate the solar heat from the solar district heating plants in this study. The LCOH concept can be used as a tool to help to make decisions on systems planning and design based on the optimization routine [39].

\subsection{Scope}

Based on a comprehensive literature survey and data collected from detailed country reports from IEASHC over the past decades, the previous literatures were mainly focused on small solar heating systems [16], [40], including domestic hot water systems for single-family homes and multi-family homes, small combined hot water and space heating systems. Only a limited number of publications on both energy and economic optimizations of large-scale solar district heating plants including natural gas boilers simultaneously in detail were found [41].

The novelty of this study is summarized as followed: 1 . The optimized objective is a hybrid $9999 \mathrm{~m}^{2}$ solar district heating plant with both flat plate collector and parabolic trough collector technologies, which is a novel design concept for solar district heating systems; 2. Two kinds of boundary conditions for LCOH 
optimization are compared in this study. The main goal of this study is to investigate ways to reduce the cost of the installation and increase the thermal performance of large solar heating plants simultaneously. Optimal area of different collectors for hybrid solar district heating plants in this study were figured out. Sensitivity analysis on storage size, orientation of PTC, different heat demands, fuel price trend and PTC price trend in the nearby future, are also investigated. This study could provide information on the optimal design of such combined solar district heating plants with both flat plate collectors and parabolic trough collectors.

\section{Method}

TRNSYS-GenOpt model, objective functions and cost investigations are introduced in this section.

\subsection{TRNSYS-GenOpt model}

A TRNSYS model on hybrid solar district heating plants has been developed in the TRNSYS 17 and validated [42]. Dynamic simulated daily (typical cloudy and sunny days) and monthly energy outputs of the hybrid solar heating plants have good agreements with the measured data. The TRNSYS model includes flat plate collectors, parabolic trough collectors, the storage tanks, natural gas boilers and so on. The quasidynamic model was used to simulate the energy output of both collector fields. Fig. 1 shows the basic process flow of the investigated plant in TRNSYS 17. GenOpt, developed by Lawrence Berkeley National Laboratory [39], was used to carry out the multivariable optimization. The general methodology of TRNSYS-GenOpt is summarized in Fig. 2. When the simulation results reach maximum or minimum aim value, the model will stop, such as minimum $\mathrm{LCOH}$ or maximum energy output. The flat plate collector field consists of two types of flat plate collectors without/with foils in series. The main components in the TRNSYS model can be found in the Table 1. 


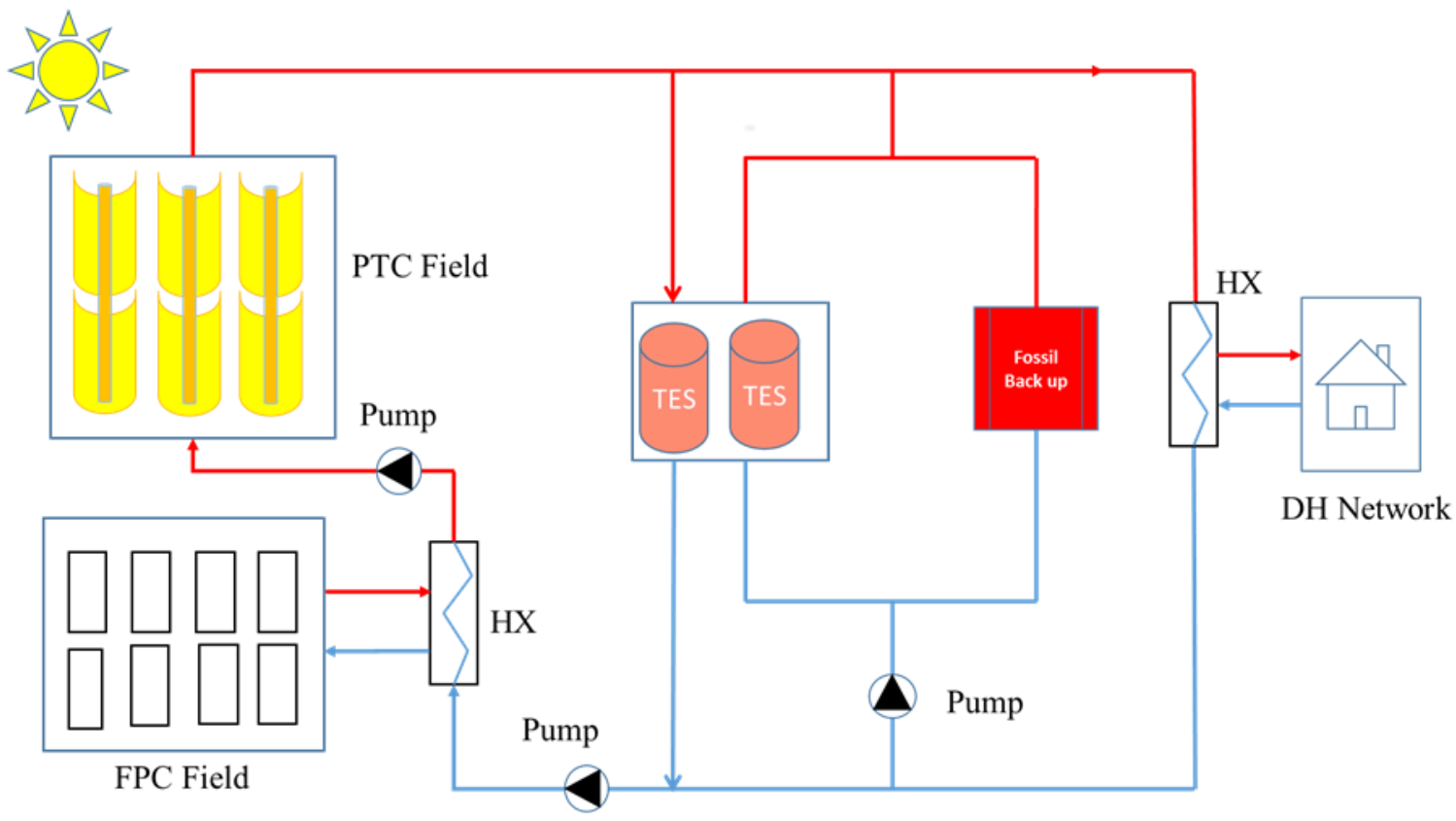

Fig.1 Simplified process flow diagram of the hybrid solar heating plant model.

Table 1. Main TRNSYS components and parameter settings (default condition) [43].

\begin{tabular}{|c|c|c|c|}
\hline Name & Component type & Main Parameters & Descriptions \\
\hline Weather data & Type 15 & $\begin{array}{l}\text { North Jutland of Denmark, Design } \\
\text { Reference Year }\end{array}$ & $\begin{array}{l}\text { Tracking model 1: fixed surface for FPC; } \\
\text { Tracking model 2: the surface rotates about a } \\
\text { fixed (user-defined) axis for PTC }\end{array}$ \\
\hline FPC & Type 1290 & $5960 \mathrm{~m}^{2}$ & Flat plate collectors without/with FEP foils \\
\hline PTC & Type 1290 & $4039 \mathrm{~m}^{2}$ & Parabolic trough collectors \\
\hline Shadow & Type 30 & $\begin{array}{l}\text { Model 1: row distance : } 5.67 \mathrm{~m} \text { Model } \\
\text { 2: row distance: } 12.6 \mathrm{~m}\end{array}$ & $\begin{array}{l}\text { Model 1: flat plate collectors; } \\
\text { Model 2: Parabolic trough collectors. }\end{array}$ \\
\hline Tank & Type 4 & $2430 \mathrm{~m}^{3}$ & Short-term storage. \\
\hline Boilers & Type 659 & $9100 \mathrm{~kW}$ & Natural gas boiler systems \\
\hline Pump & Type 3 & Varied parameters & - \\
\hline Heat load & Type 9 & Return temperature and Heat load & $\begin{array}{l}\text { Measured return temperature and heat load from } \\
\text { the district heating system (approximately } 850 \\
\text { buildings with about } 1900 \text { residents). }\end{array}$ \\
\hline
\end{tabular}




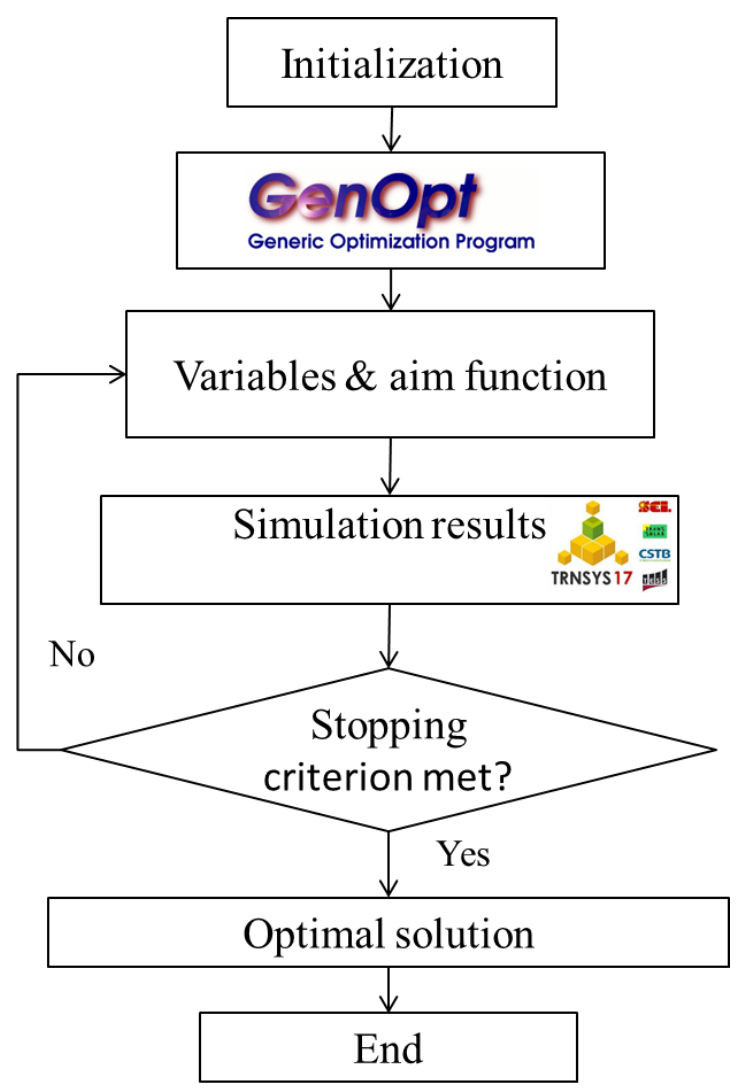

Fig.2 Flow-chart of the TRNSYS-GenOpt model.

2.2 Objective functions

151 Two different kind of objective functions for optimizations are shown. In addition, two different boundary

152 conditions of levelized cost of heat are also discussed.

$153 \quad$ 2.2.1 Energy output

154 The energy output of the hybrid solar heating plant is expressed as Equation 1. The maximum energy

155 output per square meter of the plant can be used to determine the most efficient solar heating plant during the 156 optimization. The energy output of the solar heating plant per $\mathrm{m}^{2}$ aperture area in this study is the solar heat 157 generated by the hybrid solar collector field minus heat loss from pipe loops and heat storages.

$Q_{0}=\left(Q_{p t c} \times A_{p t c}+Q_{f p c} \times A_{f p c}-Q_{l o s s}\right) /\left(A_{p t c}+A_{f p c}\right)$ 


\subsubsection{Levelized cost of heat}

Levelized cost of heat $(\mathrm{LCOH})$ was used in this study. For end-use consumers, the final and optimal heat price which consumers would pay for the district heating is interesting for the commercial market. LCOH is a fair index to use both for parabolic trough and flat plate collectors in large solar heating plants for district heating networks. The general Equation of LCOH can be found in Equation 2 [44].

$L C O H=\frac{I_{0}-S_{0}+\sum_{t=1}^{T} \frac{C_{t} \cdot(1-T R)-D E P_{t} \cdot T R}{(1+r)^{t}}-R V \cdot(1+r)^{-T}}{\sum_{t=1}^{T} E_{t} \cdot(1+r)^{-t}}$

Two boundary conditions are applied for calculations of $\mathrm{LCOH}$ for the solar district heating plants in this study. One boundary condition is elaborated only for the solar collector fields and heat storage. The other boundary condition not only includes the solar collector fields and heat storage, but also takes conventional heat supply into consideration at the same time. The former is called by net $\mathrm{LCOH}$ and the latter is called by system LCOH respectively in this study. The $D E P_{t}$ and $T R$ are regarded as zero in the residential sector [39].The simplified approach (Equations 3 and 4) is derived from the exhaustive approach (Equation 2), by making a series of assumptions in the optimization; There is no residual value; There are no incentives; Operation and maintenance costs do not change from year to year; The yearly heat generation remains constant throughout the lifetime of the system [45].

\section{Net LCOH $(n L C O H)$}

Equation 3 can be used to determine $n L C O H$. The lifetimes of both flat plate collector and parabolic trough collector field in Denmark are assumed as 30 years. Assumption of calculation discount rate is 3\% [41]. With the increase or decrease of discount rate, the $\mathrm{LCOH}$ will increase or decrease slowly.

$n L C O H=\frac{I_{S}+C_{\text {storage }}+\sum_{t=1}^{T} P_{s} \cdot(1+r)^{-t}}{\sum_{t=1}^{T} S E \cdot(1+r)^{-t}}$

\section{System $\mathrm{LCOH}(s \mathrm{LCOH})$}


The conventional natural gas boiler system is existing and quite common in Denmark. The integration of solar heating plants in existing district heating networks is a more and more common practice in Denmark. The system LCOH including the natural gas boiler system is expressed as Equation 4. The lifetime of natural gas boilers is assumed as 30 years. The main operation cost of the backup boiler systems is regarded as the operation cost of the fuel consumption.

$S L C O H=\frac{I_{S}+C_{\text {storage }}+I_{b}+\sum_{t=1}^{T}\left(P_{S}+P_{b}\right) \cdot(1+r)^{-t}}{\sum_{t=1}^{T}(S E+N E) \cdot(1+r)^{-t}}$

\subsection{Cost investigations}

The heat price from the natural gas boiler system is assumed to be $0.57 \mathrm{DKK} / \mathrm{kWh}$ in this study. The assumed cost of the flat plate collector field with collectors without FEP foils is shown by Equation 5. The cost of the flat plate collector field with collectors with FEP foils is assumed to be $7.6 \%$ higher than that of the flat plate collector field with collectors without FEP foils. The cost of the parabolic trough collector field and the storage tank is expressed by Equation 6 [46] and 7 [40] respectively. The cost of parabolic trough collector field is $40 \%-70 \%$ higher than the cost of flat plate collector field regarding of the size. The operation and maintenance cost of the flat plate collector field every year is assumed as follows: a) 2 DKK/MWh heat produced for maintenance fee [47]; b) $1.5 \mathrm{kWh}$ electricity/100kWh heat produced for operation (2.3 DKK/kWh electricity) [40]. The operation and maintenance cost of the parabolic trough collector field every year is assumed to be $0.8 \%$ of the initial cost [33].

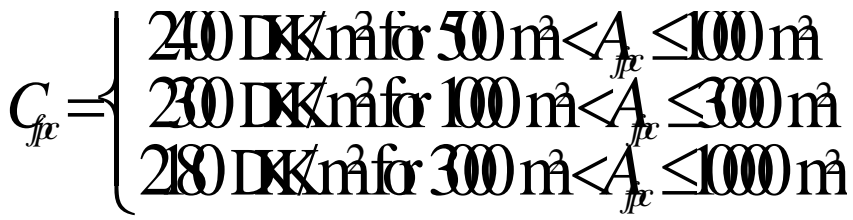

The cost function of the parabolic trough collector field is as Equation 6 [46]

$C_{p t c}=13925 \times A_{p t c}{ }^{-0.17}$ 
203

\section{Case study}

A hybrid solar district heating plant with flat plate collectors and parabolic trough collectors is used as the reference case in the optimization. Details about the hybrid solar heating plants, climate data and heat demand are shown in the section 3.1 and 3.2.

\subsection{Taars solar heating plant}

Taars plant with flat plate collectors and parabolic trough collector was constructed in August 2015. The hybrid plant is supported by the Danish Energy Agency through the Energy Technology Development and Demonstration Program (EUDP). The flat plate collector field preheats the return water from the district heating networks to about $75{ }^{\circ} \mathrm{C}$. Then the preheated water from the flat plate collector field is heated by the parabolic trough collector field to about $95{ }^{\circ} \mathrm{C}$. Main design and technical parameters for the plant can be found in Table 2 and Table 3 respectively. The solar collector field consists of flat plate collectors and parabolic trough collectors in series. In the flat plate collector subfield, half of the collectors are without FEP foils (HTHEATboost 35/10) and the other half of the collectors are with FEP foils (HTHEATstore 35/10). The flat plate collectors are delivered by Arcon-Sunmark A/S [48]. The collectors without the foils are placed first in the rows, while the collectors with the foils are placed last in the rows. The tilt of flat plate collectors is $50^{\circ}$. The return water from the district heating network is preheated by the flat plate collector field. Then the preheated water is heated up to a required temperature by the parabolic trough collectors. The parabolic trough collectors were delivered by Aalborg CSP A/S [33]. The orientation of parabolic trough collectors is N-S orientation with $13.4^{\circ}$ towards west. The existing natural gas boilers are the backup systems for the district heating network. The efficiency parameters of the investigated solar collectors based on the aperture area can be found in Table 4 . 
Table 2. Main design parameters of the Taars plant.

\begin{tabular}{cc}
\hline Parameters & Taars \\
& (Denmark) \\
\hline Latitude & $57.39^{\circ} \mathrm{N}$ \\
Lltitute & $10.11^{\circ} \mathrm{E}$ \\
Parabolic trough collector field & $48 \mathrm{~m}$ \\
(Aperture area) & $4039 \mathrm{~m}^{2}$ \\
Flat plate collector field (Aperture & \\
area) & $5960 \mathrm{~m}^{2}$ \\
Fossil backup -Natural gas boilers & $9.1 \mathrm{MW}^{\text {Storage tank (2) }}$ \\
\hline
\end{tabular}

Table 3. Main technical parameters of the collector fields.

\begin{tabular}{ccc}
\hline Parameters & PTC & FPC \\
\hline Solar collector fluid & Water & $35 \%$ propylene \\
glycol/water \\
Collector row distance, $\mathrm{m}$ & 12.6 & 5.67 \\
Azimuth, & -13.4 & 0 \\
Tilt, & - & 50 \\
\hline
\end{tabular}

Table 4. Parameters of the investigated solar collectors.

\begin{tabular}{cccccccc}
\hline$\eta_{0}$ & $\mathrm{~b}_{0}$ & $\mathrm{~b}_{1}$ & $\mathrm{~K}_{\theta \mathrm{d}}$ & $\mathrm{c}_{1},\left[\mathrm{~W} /\left(\mathrm{m}^{2} \cdot \mathrm{K}\right)\right]$ & $\mathrm{c}_{2},\left[\mathrm{~W} /\left(\mathrm{m}^{2} \cdot \mathrm{K}^{2}\right)\right]$ & $\mathrm{c}_{3},\left[\mathrm{~kJ} /\left(\mathrm{m}^{2} \cdot \mathrm{K}\right)\right]$ & \\
\hline 0.839 & 0.1 & 0 & 0.98 & 2.596 & 0.016 & 7.321 & HEATboost 35/10 \\
0.802 & 0.1 & 0 & 0.93 & 2.226 & 0.010 & 7.876 & HEATstore 35/10 \\
0.75 & 0.27 & 0 & 0.038 & 0.04 & 0 & 4.00 & PTC \\
\hline
\end{tabular}

$232 \frac{Q}{A}=\eta_{0} K_{\theta b}(\theta) G_{b}+\eta_{0} K_{\theta d}(\theta) G_{d}-c_{1}\left(T_{m}-T_{a}\right)-c_{2}\left(T_{m}-T_{a}\right)^{2}-c_{3} \frac{d T_{m}}{d t}$ 
$K_{\theta b}(\theta)=1-b_{0}\left(\frac{1}{\cos \theta}-1\right)-b_{1}\left(\frac{1}{\cos \theta}-1\right)^{2}, \theta \leq 60^{\circ}$

234 When $\boldsymbol{C}>60^{\circ}$, the IAM is linearized from the value at $60^{\circ}$ to a value of zero at $90^{\circ}$.

235

236

\subsection{Climate data and heat demand}

Fig. 3 shows the monthly global radiation, DNI and average ambient temperature in the Design Reference Year (DRY) of Northern Jutland of Denmark [49]. Yearly DNI and global radiation in the DRY are 1150 and $1030 \mathrm{kWh} / \mathrm{m}^{2}$ respectively. The district heating network consists of approximate 850 buildings with about 1900 consumers. The typical design heat demand of the district heating network is shown in Fig.4. The heat demand was measured from the district heating network as the typical design parameter for the hybrid solar heating plant. The total heat demand is 20167 MWh per year. The heat demand is quite low in the summer and high in the winter.

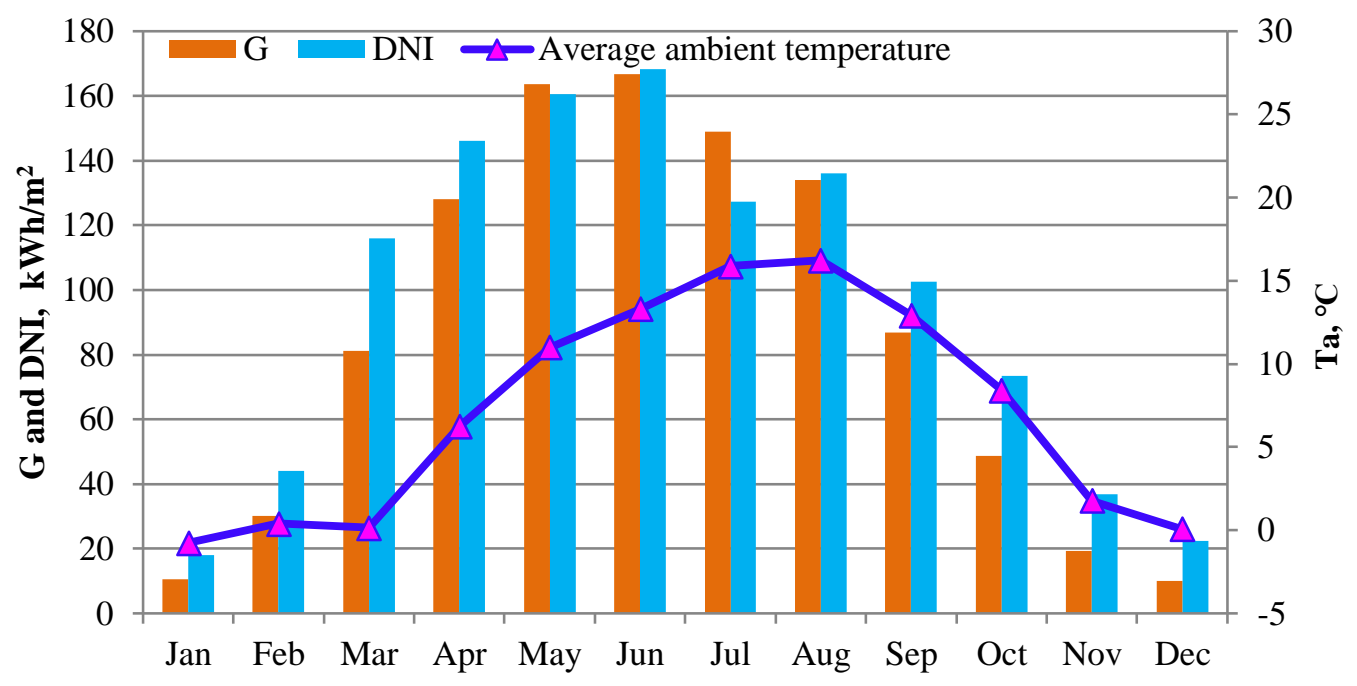

Fig.3 Monthly global radiation, DNI and average ambient temperature in the DRY (Northern Jutland, Denmark). 


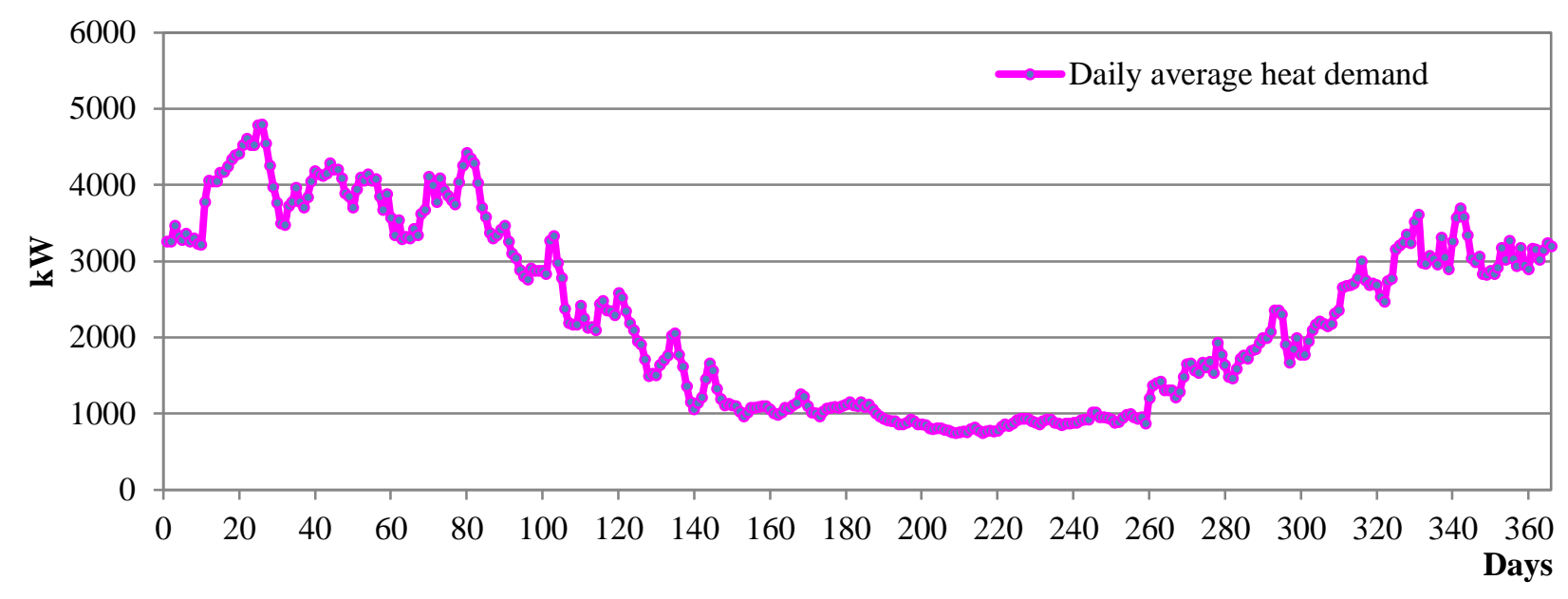

Fig.4 Typical daily average heat demand of the district heating network [33].

\section{Results}

249 Influence of storage size, orientation of PTC, different heat demands, fuel price trend and PTC price trend 250 in the nearby future, are investigated and analyzed in this section. 


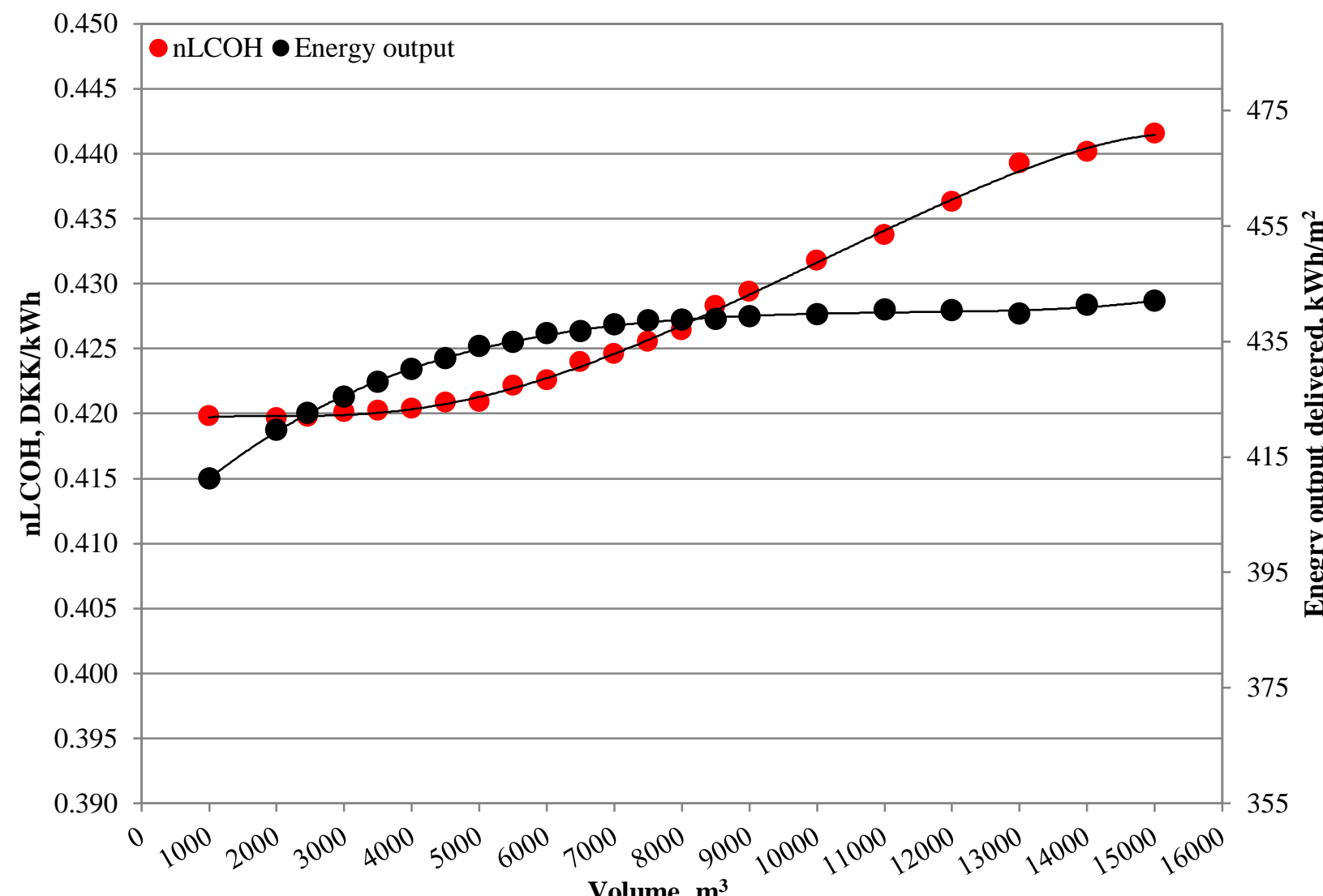

Fig.5 The influence of the storage volume on net LCOH and yearly solar energy output of the Taars plant (All the other variables are kept constant as in the Taars plant).

Areas of both collector fields and volume of the storage tanks are important design parameters for the hybrid solar heating plant. The optimal storage volume and solar collector areas of the solar collector fields depend strongly on each other. Fig.5 shows the influence of the storage volume on the $n L C O H$ and solar energy output in the reference case. The $n L C O H$ of the Taars plant is $0.420 \mathrm{DKK} / \mathrm{kWh}$. The $n L C O H$ almost has the same level of $0.420 \mathrm{DKK} / \mathrm{kWh}$ when the storage volume varies between $2430 \mathrm{~m}^{3}$ and $5000 \mathrm{~m}^{3}$. The energy output of the plant delivered to the district heating network can increase from $422 \mathrm{kWh} / \mathrm{m}^{2}$ to 434 $\mathrm{kWh} / \mathrm{m}^{2}$. When the heat storage volume is $7000 \mathrm{~m}^{3}$, the energy output delivered to the district heating network almost peaks at $438 \mathrm{kWh} / \mathrm{m}^{2}$. For further increased storage volumes, the thermal performance is not much increased. 5000-7000 $\mathrm{m}^{3}$ could be the reasonable storage volume for the Taars plant. 


\subsection{Area of both collector fields}

It appears from Fig. 5 that a larger storage tank not only can increase the energy output of the plant, but also keeps the $n L C O H$ at a low constant level. So optimal areas of the collector fields based on four heat storage scenarios, including $2430 \mathrm{~m}^{3}$ - scenario $1 \mathrm{a} / \mathrm{b}, 5000 \mathrm{~m}^{3}-$ scenario $2 \mathrm{a} / \mathrm{b}, 7500 \mathrm{~m}^{3}$ - scenario $3 \mathrm{a} / \mathrm{b}$ and $10000 \mathrm{~m}^{3}-$ scenario $4 \mathrm{a} / \mathrm{b}$, are investigated and compared to the reference case. In the whole scenarios, the tilt of the flat plate collectors and the orientation of the parabolic trough collectors are also optimized to reach the minimum $n L C O H$. The optimal tilt of the flat plate collectors is $35^{\circ}$ and the optimal orientation of the parabolic trough collectors is E-W orientation in the scenarios $1 \mathrm{a}-4 \mathrm{a}$ and $1 \mathrm{~b}-4 \mathrm{~b}$. The areas of both flat plate collector field and parabolic trough collectors are between 100 and $10000 \mathrm{~m}^{2}$ in the optimizations. Fig. 6 shows the optimal collector areas of different collectors based on the aim function of maximum energy output delivered to the consumers. It is suggested that the optimal collector field should consist of mainly parabolic trough collectors without flat plate collectors for four scenarios. Fig. 7 shows the optimal collector areas of different collectors based on the aim function of minimum $n L C O H$. It is suggested that the optimal collector field should integrate flat plate collectors and parabolic trough collectors in series to reach minimum $n L C O H$ points with the range $0.367-0.400 \mathrm{DKK} / \mathrm{kWh}$. The solar fraction of the Taars plant is 21.6\%. The solar fractions of the investigated four scenarios $1 \mathrm{~b}-4 \mathrm{~b}$ in Fig. 7 are placed in the interval from $18 \%$ to $23 \%$. The comparison of Taars plant and scenario $1 \mathrm{~b}$ in Fig.7 shows that the solar collector fields was oversized during the design phase, which causes that the net $\mathrm{LCOH}$ of the Taars plant is higher than that of scenario $1 \mathrm{~b}$. But the net $\mathrm{LCOH}$ of Taars plant is still lower than the price for natural gas boiler systems. In addition, the comparison of Taars plant and scenario $4 \mathrm{~b}$ in Fig.7 shows that if there were a $10000 \mathrm{~m}^{3}$ large storage volume, the optimal solar fraction could have increased to $23 \%$ with lower heat price, then the cost performance of such large-scale solar heating plants increases a lot. 


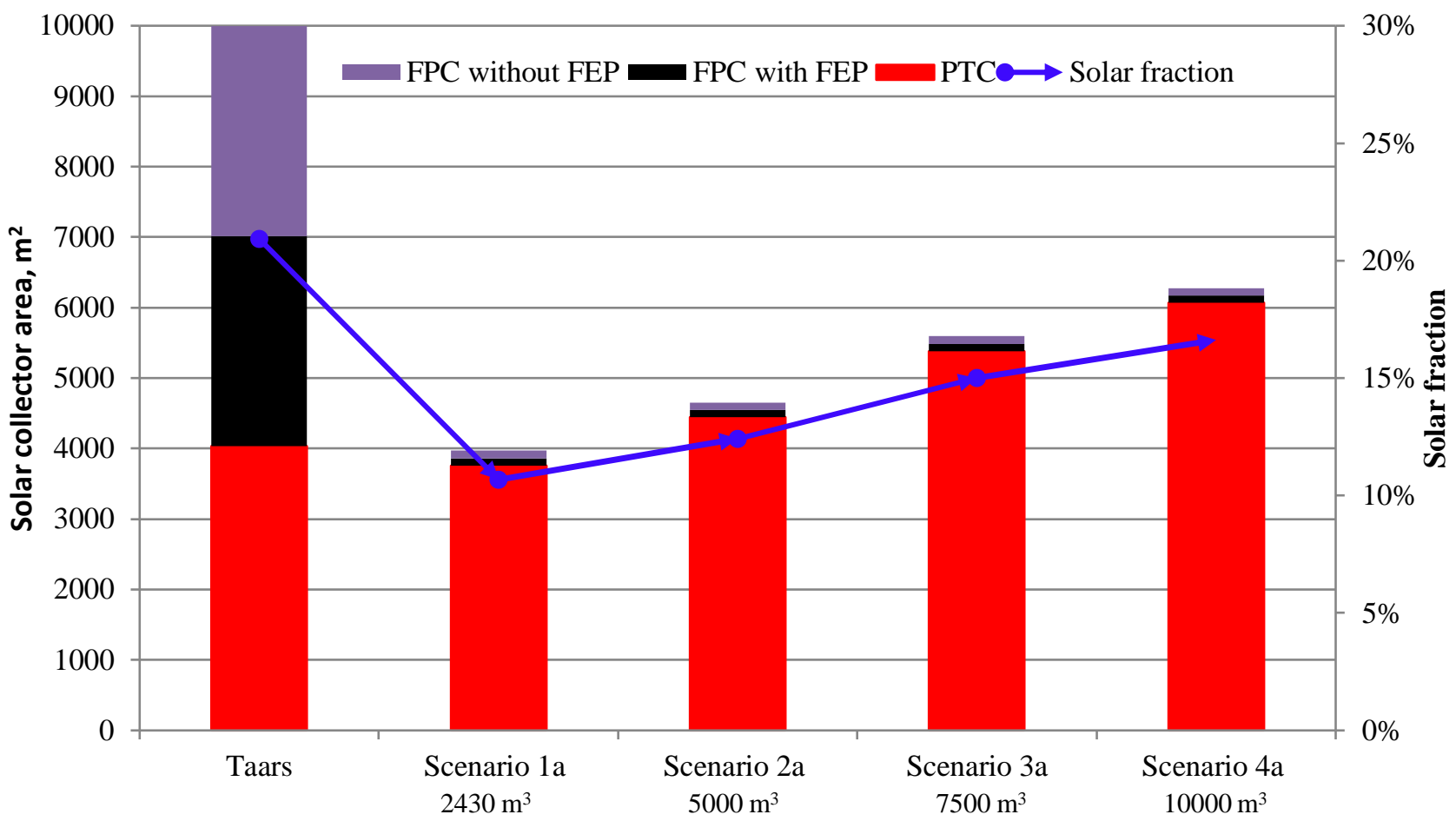

287 Fig.6 Optimal solar collector area and solar fraction of the investigated scenarios 1a-4a based on the aim function of maximum energy output (All the other variables are kept constant as the Taars plant).

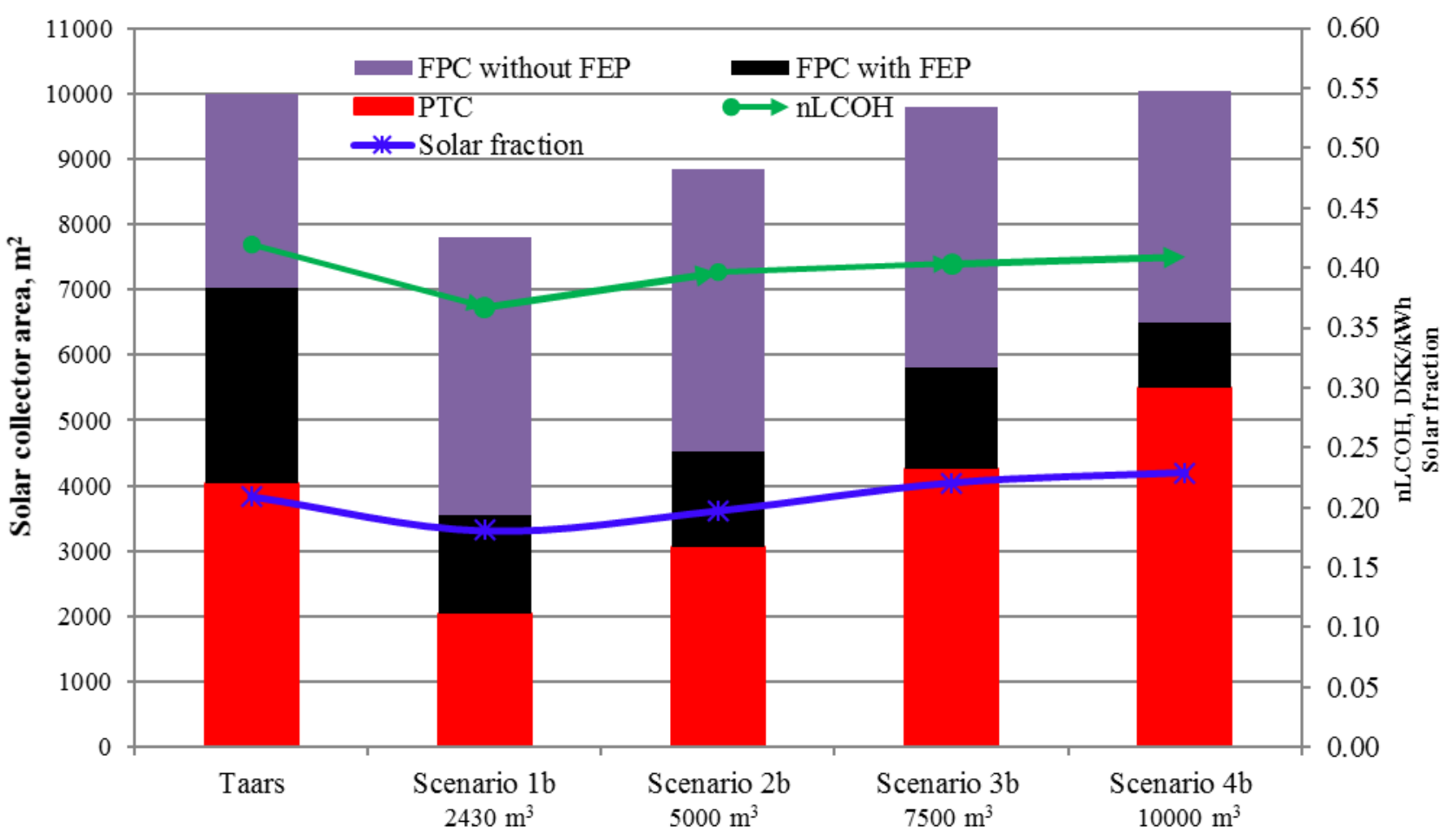


Fig.7 Optimal solar collector area, net $L C O H$ and solar fraction of the investigated scenarios $1 \mathrm{~b}-4 \mathrm{~b}$ based on the aim function of minimum $n L C O H$ (All the other variables are kept constant as in the Taars plant).

Based on the results in Figs. 6 and 7, it is seen that quite different conclusions appear from different aim functions for the 4 scenarios. Various target groups would use different aim functions to benefit from the results. On the one hand, parabolic trough collectors are more efficient than flat plate collectors for high temperature levels. On the other hand, the price of parabolic trough collectors is higher than the price of flat plate collectors for high temperature levels. From the scenarios 1-4 in Fig. 7, it is shown that the combination of flat plate collectors and parabolic trough collectors in series can increase the cost-performance of the solar district heating plants, which is interesting for the commercial market and end-use consumers.

\subsection{Orientation of the parabolic trough collectors}

The orientation of the PTC fields affects the way of tracking and the received beam radiation. The N-S orientation is always regarded as the optimal orientation of concentrating solar power plants [50]. The typical E-W and N-S orientations are compared in Fig.8. Fig. 8a and Fig. 8b show the reference case (the Taars plant) and the optimal case of scenario 1 with both typical orientations in Fig. 7 respectively. The comparison between Figs. 8a and 8b indicates that the parabolic trough collectors are defocused a lot from May to August in the reference case. The defocus of the parabolic trough collector field causes a low heat production of the plant and a high $n L C O H$. Furthermore, Fig.8 shows that the PTC field with N-S orientation produces higher heat in the summer months than the PTC field with E-W orientation. As shown in Fig.4, the heat demand of the district heating network in the summer is very low. The PTC field with N-S orientation may cause excess heat production if the PTC works normally in the summer. It can be seen that in Fig. $8 \mathrm{~b}$ that the monthly energy output of the PTC field with N-S orientation can be higher than $100 \mathrm{kWh} / \mathrm{m}^{2}$. So the PTC field with N-S orientation has to be defocused a lot in sunny days in the summer. On the contrary, the PTC field with E-W orientation produces lower heat in the summer due to large incidence angle losses. In addition, the PTC field with E-W orientation produces more solar heat in the spring, autumn and winter seasons while the heat demand is also high. In order to avoid the heat overproduction of the PTCs in the 
summer and harvest the thermal performance of the PTC in spring and autumn, E-W orientation is the suggested orientation for the PTC field for the district heating network in this study.
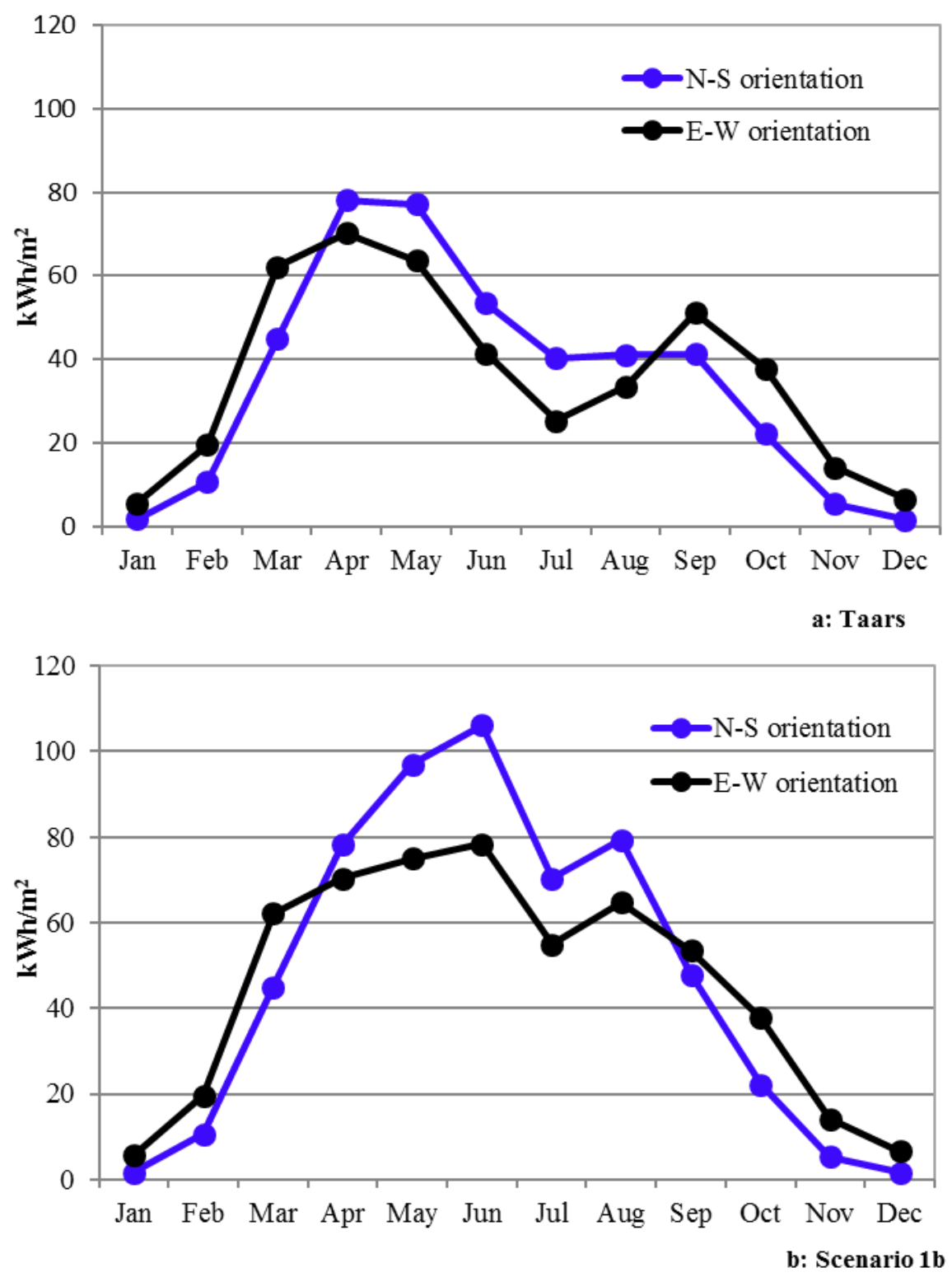

318 Fig.8 The influence of typical orientation on the energy output of the parabolic trough field (a: the reference Taars plant; b: Scenario 1b- optimal case for Taars plant). 


\subsection{Heat demand}

The heat demand of the district heating network influences the operation strategy of the solar heating plant directly, especially in the summer. Larger heat demand could improve the operation of parabolic trough collectors in the summer. Seven heat demand scenarios varying from $0 \%$ to $60 \%$ extra demand compared to the demand in Taars are shown in Table 5. All the other variables are kept constant as in the Taars plant. Compared to existing flat plate collector plants in Denmark, the energy output of the flat plate collector field in Taars produces higher solar heat. That is due to the fact that the flat plate collectors work at relatively low operation temperature in the hybrid solar heating plant. With the increase of the heat demand, the energy output of the flat plate collector field increases slowly. But the energy output of the parabolic trough collector field increases sharply with larger heat demand. That is because the parabolic trough collector field is defocused and not used fully in the summer in the reference case. When the heat demand increases by $60 \%$, the yearly output of the PTC field can increase from $418 \mathrm{kWh} / \mathrm{m}^{2}$ to $528 \mathrm{kWh} / \mathrm{m}^{2}$ and the $n L C O H$ can be reduced from 0.420 to $0.363 \mathrm{DKK} / \mathrm{kWh}$. So the collector field is oversized and should be smaller based on 333 the heat demand in Taars. Another solution for the reference case is that a larger storage tank should be used, 334 as indicated in Fig.5.

Table 5. $n L C O H$ based on different heat demands.

\begin{tabular}{|c|c|c|c|c|}
\hline & \multicolumn{3}{|c|}{ Annual energy output, kWh/m² } & \multirow{2}{*}{ NLCOH, DKK/kWh } \\
\cline { 1 - 4 } Heat demand & FPC field & PTC field & The whole plant excluding heat loss & 0.420 \\
\hline 0 ( Taars ) & 449 & 418 & 422 & 0.405 \\
\hline$+10 \%$ & 454 & 447 & 437 & 0.395 \\
\hline$+20 \%$ & 458 & 472 & 449 & 0.388 \\
\hline$+30 \%$ & 460 & 487 & 457 & 0.380 \\
\hline$+40 \%$ & 463 & 506 & 466 & 0.374 \\
\hline$+50 \%$ & 465 & 521 & 474 & 0.363 \\
\hline$+60 \%$ & 467 & 528 & 478 & \\
\hline
\end{tabular}




\subsection{Fuel price trend}

The price of natural gas for household consumers in Denmark fluctuates a lot year by year, even month by month [25], [26]. Four increased fuel price scenarios varying from $0 \%$ to $30 \%$ price increase are shown in Table 6 to determine the system LCOH. The system LCOH of the Taars plant is $0.54 \mathrm{DKK} / \mathrm{kWh}$. The system $\mathrm{LCOH}$ is $5 \%-9 \%$ lower than traditional natural gas boiler systems because of the application of the solar heating collectors in Table 6 .

Table 6. $s L C O H$ based on different fuel fees.

\begin{tabular}{cc}
\hline Price of the fuel, DKK/kWh & $s L C O H, \mathrm{DKK} / \mathrm{kWh}$ \\
\hline 0.57 (Taars) & 0.54 \\
0.63 & 0.59 \\
0.68 & 0.63 \\
0.74 & 0.67 \\
\hline
\end{tabular}

\subsection{Price trend of parabolic trough collectors}

The high price is the main barrier for the parabolic trough collectors to be applied widely in the market compared to the flat plate collectors. With the commercial development of PTC just started in 1970s [51], there is huge decrease potential of the cost of PTC. So four PTC price scenarios varying from $0 \%$ to $-50 \%$ reduction in price were investigated to obtain an overview of the development for PTC technology in district heating networks in the future. Areas of the collectors, tilt of the FPC and orientation of the PTC were optimized simultaneously to reach minimum $n L C O H$. Fig.9 shows the optimal design points for all the PTC price scenarios. The optimal tilt of flat plate collectors is $35^{\circ}$. The optimal orientation of parabolic trough collectors is $\mathrm{E}-\mathrm{W}$ orientation. All the other variables are kept as in the Taars plant. When the price of PTC decreases by $50 \%$, the optimal $n L C O H$ of the plant can be reduced from $0.367 \mathrm{DKK} / \mathrm{kWh}$ to 0.247 $\mathrm{DKK} / \mathrm{kWh}$. It can be found that the design strategy of flat plate collectors and parabolic trough collectors in series is feasible and optimal in order to reach minimum net LCOH in all the scenarios. 


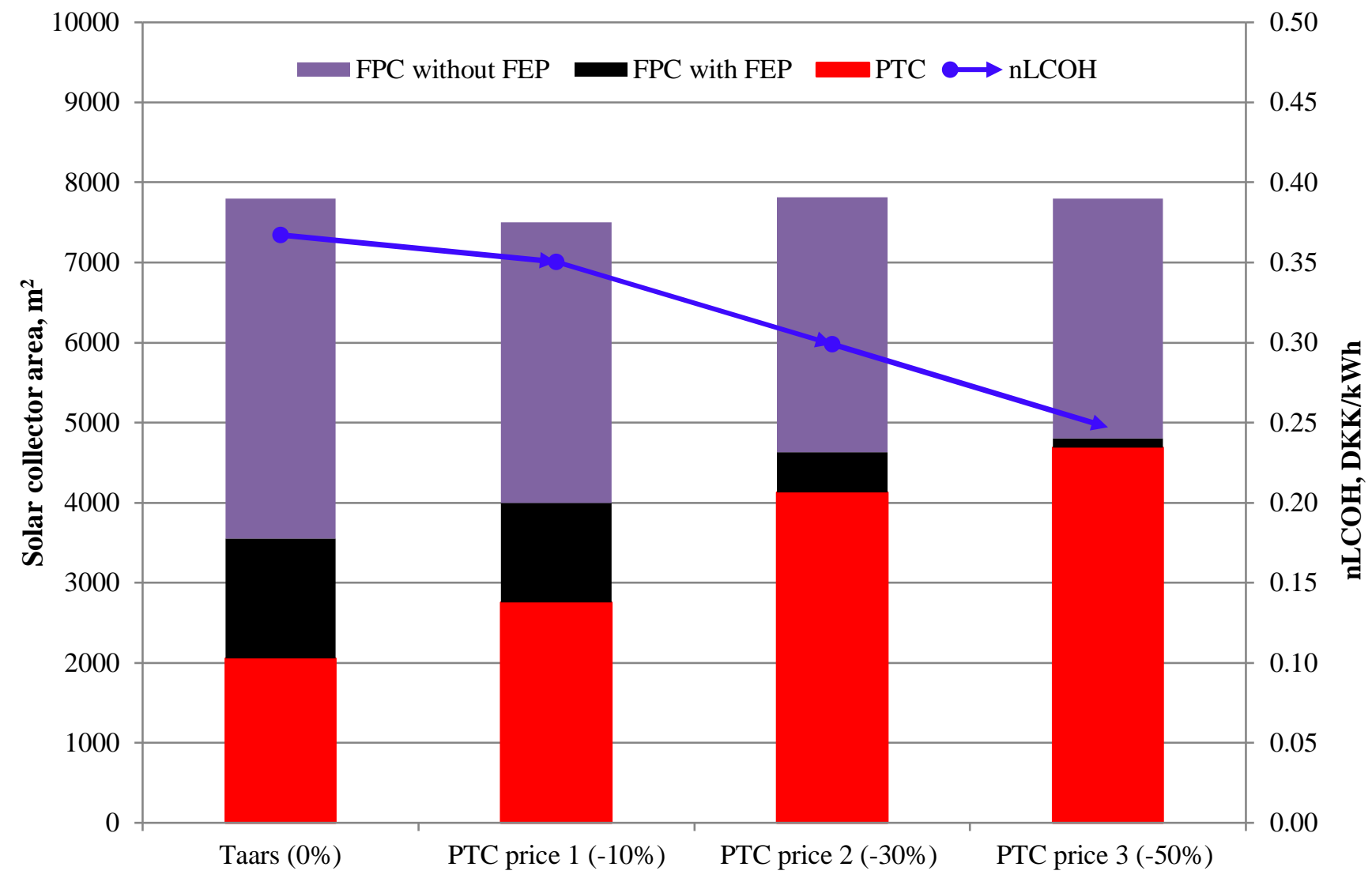

Fig.9 Minimum $n L C O H$ and optimal design collector areas based on different prices of the PTC.

\section{Discussion}

The studied plant is the first pilot large-scale solar heating plant with flat plate collectors and parabolic trough collectors in series for district heating networks in Europe, even worldwide. The boiling problem for solar district heating plants in the summer is one of main factors to limit the size of plants, if there are not seasonal storage. On the one hand, the application of parabolic trough collectors can easily be defocused to avoid the overheat production, which can increase the flexibility of solar heating plants in the whole energy system, compared to evacuated tube collectors and compound parabolic collectors. On the other hand, the defocus of the parabolic trough collector reduces the cost-effective competitiveness of the hybrid solar heating plants. The integration of parabolic trough collectors can also guarantee that flat plate collectors 
work at relatively low operation temperature and produce more than the normal solar heating plants. The investigations in this study figure out the optimal solar collector areas for the Taars plant.

In addition, Fresnel collectors is another line-focusing collector, which arouses increasing interests in the last decade. Fresnel collectors have cheaper price and higher land use efficiency than parabolic trough collectors, while it has lower solar-to-power efficiency. If the advantages of Fresnel collectors were enough strong to the low efficiency, the Fresnel collectors could be an optional alterative collector type to parabolic trough collectors for such hybrid solar district heating plants. All in all, the integration of evacuated tube collectors, compound parabolic collectors, or Fresnel collectors with flat plate collectors due to the cheaper price could also be interesting to investigate for large-scale hybrid solar district heating plants in the future work.

\section{Conclusions and future work}

Analyses based on levelized cost of heat for large scale solar district heating plants have been carried out. An optimization approach based on TRNSYS-GenOpt was introduced. Multi variable and function optimizations of a hybrid solar heating plant were carried out. The LCOH of hybrid solar heating plants for different scenarios in the near future was also figured out. The following conclusions can be drawn:

The net $\mathrm{LCOH}$ of the Taars plant is $0.42 \mathrm{DKK} / \mathrm{kWh}$. The lowest net LCOH of the optimized hybrid solar heating plant $(0.367 \mathrm{DKK} / \mathrm{kWh})$ is much lower than the average price of heat from the natural gas boilers (0.57 DKK/kWh). The use of parabolic trough collector in the solar district heating systems is cost effective.

The system LCOH of the Taars plant can be reduced by about 5-9\% by using solar collectors in district heating networks in this study.

For the investigated district heating network, parabolic trough collectors with E-W orientation are more suitable than that with N-S orientation due to the high solar fraction during the summer. The low heat demand/collector area ratio limits the potential of parabolic trough collectors as long as the plant is not 
equipped with large heat stores. Heat stores with large volumes are needed in order to fully utilize the 391 parabolic trough collectors.

392 The concept with flat plate collectors and parabolic trough collectors in series for district heating networks 393 is technical-economic feasible in Denmark compared to the heat price of conventional natural gas boiler 394 systems. The optimization of area of the collectors and storage size based on the heat demand should be 395 addressed in the planning and design phase of hybrid solar heating plants. The results not only can provide 396 useful recommendations to designers, but also result in the lowest heat price for the end-use domestic 397 consumers.

\section{Acknowledgements}

399 The first author really appreciates the China Scholarship Council (No.201506120074) for the financial 400 support for the PhD study at the Technical University of Denmark. Special thanks are expressed to Aalborg 401 CSP A/S (Andreas Zourellis, Jan Holst Rothman, Steffen Rovsing Møller and Per Aasted) for the 402 information provided. This work is a part of an EUDP project financed by the Danish Energy Agency and 403 the IEA-SHC Task 55 "Towards the Integration of Large SHC Systems into DHC Networks". 
$411 \quad$ Nomenclature

412 Abbreviations

$413 \quad$ DH district heating

$414 \quad D K K \quad$ Danish Krone

$415 \quad D R Y$ design reference year

416 DNI monthly direct normal irradiance, $\mathrm{kWh} / \mathrm{m}^{2}$

$417 \quad E-W \quad$ East-west

418 FEP fluorinated ethylene propylene

$419 \quad$ FPC flat plate collector

$420 \quad H X \quad$ heat exchanger

$421 \quad$ IEA International Energy Agency

$422 \quad \mathrm{LCOH}$ levelized cost of heat, DKK $/ \mathrm{kWh}$

$423 L C O E$ levelized cost of energy, DKK $/ \mathrm{kWh}$

$424 n L C O H$ net levelized cost of heat, DKK/kWh

$425 \quad N-S \quad$ North-south

$426 \quad$ PTC parabolic trough collector

$427 \quad$ SHC solar heating and cooling

$428 \quad s L C O H \quad$ system levelized cost of heat, DKK $/ \mathrm{kWh}$

429 TES Thermal energy storage 
$431 \quad A_{p t c} \quad$ aperture area of the parabolic trough collector field, $\mathrm{m}^{2}$

$432 \quad A_{f p c} \quad$ aperture area of the flat plate collector field, $\mathrm{m}^{2}$

$433 \quad C_{p t c} \quad$ cost of the parabolic trough collector field, DKK $/ \mathrm{m}^{2}$

$434 \quad C_{f p c} \quad$ cost of the flat plate collector field, DKK $/ \mathrm{m}^{2}$

$435 \quad c_{1} \quad$ heat loss coefficient at $(\mathrm{Tm}-\mathrm{Ta})=0, \mathrm{~W} /\left(\mathrm{m}^{2} \cdot \mathrm{K}\right)$

$436 \quad c_{2} \quad$ temperature dependence of the heat loss coefficient, $\mathrm{W} /\left(\mathrm{m}^{2} \cdot \mathrm{K}^{2}\right)$

$437 \quad c_{3} \quad$ effective thermal capacity, $\mathrm{J} /\left(\mathrm{m}^{2} \cdot \mathrm{K}\right)$

$438 \quad C_{t} \quad$ operation and maintenance costs (year t), DKK

$439 C_{\text {storage }}$ specific costs of the tanks incl. installation (excl. VAT and subsidies), DKK $/ \mathrm{m}^{3}$

$440 \quad D E P_{t} \quad$ asset depreciation (year t), DKK

$441 \quad E_{t} \quad$ Energy generated (year t), $\mathrm{kWh}$

$442 \quad G \quad$ monthly global radiation, $\mathrm{kWh} / \mathrm{m}^{2}$

$443 \quad I_{s} \quad$ specific solar thermal system costs incl. installation (excl. VAT and subsidies), DKK $/ \mathrm{m}^{2}$

$444 \quad I_{b} \quad$ specific boiler system costs incl. installation (excl. VAT and subsidies), DKK

$445 \quad N E \quad$ heat from the natural gas boiler system, $\mathrm{kWh}$

$446 \quad P_{s} \quad$ operation \& maintenance expenditures of the solar plant in the year $\mathrm{t}$, DKK

$447 \quad P_{b} \quad$ operation \& maintenance expenditures of the natural gas boiler system in the year $\mathrm{t}, \quad \mathrm{DKK}$

$448 \quad Q_{p t c} \quad$ yearly energy output of the parabolic trough collector field, $\mathrm{kWh} / \mathrm{m}^{2}$ 
$449 Q_{f p c} \quad$ yearly energy output of the flat plate collector field, $\mathrm{kWh} / \mathrm{m}^{2}$

$450 \quad Q_{\text {loss }} \quad$ yearly heat loss in solar loop pipe and thermal energy storage, $\mathrm{kWh}$

$451 \quad Q_{0} \quad$ yearly energy output of the whole collector field, $\mathrm{kWh} / \mathrm{m}^{2}$

$452 \quad r \quad$ discount rate, $\%$

$453 \quad R V \quad$ residual value, DKK

$454 \quad S E \quad$ specific useful energy delivered by the solar thermal system in the year $\mathrm{t}$ (thermal losses in pipe $455 \quad$ loop and thermal storage considered), $\mathrm{kWh}$

$456 \quad S_{0} \quad$ subsidies and incentives, DKK

$457 \quad T_{a} \quad$ ambient temperture, ${ }^{\circ} \mathrm{C}$

$458 \quad I_{0} \quad$ initial investment, DKK

$459 \quad T R \quad$ corporate tax rate, $\%$

$460 \quad T \quad$ period of use (solar thermal system life time in years), a

$461 \quad t \quad$ year within the period of use $(1,2, \ldots \mathrm{T})$

462 Greek Symbols

$463 \quad \eta_{0} \quad$ optical efficiency,-

464 Subscripts

465 th thermal 


\section{References}

468 [1] F. M. Rad and A. S. Fung, "Solar community heating and cooling system with borehole thermal energy storage - Review of systems,” Renew. Sustain. Energy Rev., vol. 60, pp. 1550-1561, 2016.

470 [2] M. Hazami, N. Naili, I. Attar, and A. Farhat, "Solar water heating systems feasibility for domestic 471 requests in Tunisia: Thermal potential and economic analysis," Energy Convers. Manag., vol. 76, pp. 599-608, 2013.

473 [3] J. Deng, Z. Tian, J. Fan, M. Yang, S. Furbo, and Z. Wang, "Simulation and optimization study on a solar space heating system combined with a low temperature ASHP for single family rural residential houses in Beijing," Energy Build., vol. 126, pp. 2-13, 2016.

[4] K. Çomaklı, U. Çakır, M. Kaya, and K. Bakirci, "The relation of collector and storage tank size in

[5] E. Kaçan, K. Ulgen, and E. Kaçan, "What is the effect of optimum independent parameters on solar heating systems?," Energy Convers. Manag., vol. 105, pp. 103-117, Nov. 2015.

[6] H. Li, W. Xu, Z. Yu, J. Wu, and Z. Yu, "Discussion of a combined solar thermal and ground source heat pump system operation strategy for office heating," Energy Build., vol. 162, pp. 42-53, 2018.

[7] E. Bellos, C. Tzivanidis, K. Moschos, and K. A. Antonopoulos, "Energetic and financial evaluation of solar assisted heat pump space heating systems," Energy Convers. Manag., vol. 120, pp. 306-319,

[8] N. Pardo García, G. Zubi, G. Pasaoglu, and R. Dufo-López, "Photovoltaic thermal hybrid solar collector and district heating configurations for a Central European multi-family house," Energy Convers. Manag., vol. 148, pp. 915-924, Sep. 2017.

[9] A. Ramos, M. A. Chatzopoulou, I. Guarracino, J. Freeman, and C. N. Markides, "Hybrid photovoltaic-thermal solar systems for combined heating, cooling and power provision in the urban 
environment," Energy Convers. Manag., vol. 150, pp. 838-850, Oct. 2017.

491 [10] F. Bava, J. Dragsted, and S. Furbo, "A numerical model to evaluate the flow distribution in large solar collector fields in different operating conditions," Sol. Energy, vol. 143, pp. 11-14, 2016.

493 [11] F. Bava and S. Furbo, "A numerical model for pressure drop and flow distribution in a solar collector with horizontal U-connected pipes,” Sol. Energy, vol. 134, pp. 264-272, 2016.

[12] F. Bava and S. Furbo, "Development and validation of a detailed TRNSYS-Matlab model for large solar collector fields for district heating applications,” Energy, vol. 135, pp. 698-708, 2017.

[13] J. Wang and Y. Yang, "Energy, exergy and environmental analysis of a hybrid combined cooling heating and power system utilizing biomass and solar energy," Energy Convers. Manag., vol. 124, pp. 566-577, Sep. 2016.

[14] International Energy Agency, "IEA Solar Heating \& Cooling Programme," https://www.iea-shc.org/, 2017. [Online]. Available: Mar.2017.

[15] Jan-Olof Dalenbäck, "IEA SHC Task 7 CENTRAL SOLAR HEATING PLANTS WITH SEASONAL STORAGE - CSHPSS 1981-1990," in Edited Status Report.

[16] F. Mauthner and W. Weiss, “. Solar heat worldwide: markets and contribution to the energy supply 505 2014," Int. Energy Agency-Solar Heat. Cool. Progr., 2016.

[17] M. Fish, M. Guigas, and J. Dalenback, “A review of large-scale solar heating systems in Europe,” Sol. Energy, vol. 63, no. 6, pp. 355-66, 1998.

[18] M. De Guadalfajara, M. A. Lozano, and L. M. Serra, "Evaluation of the potential of large solar heating plants in Spain,” Energy Procedia, vol. 30, pp. 839-848, 2012.

[19] D. Bauer, R. Marx, J. Nußbicker-Lux, F. Ochs, W. Heidemann, and H. Müller-Steinhagen, “German central solar heating plants with seasonal heat storage," Sol. Energy, vol. 84, no. 4, pp. 612-623, 2010. 
[20] D. Olsthoorn, F. Haghighat, and P. A. Mirzaei, "Integration of storage and renewable energy into district heating systems: A review of modelling and optimization," Sol. Energy, vol. 136, pp. 49-64, 2016.

[21] V. Tulus, D. Boer, L. F. Cabeza, L. Jimenez, and G. Guillen-Gosalbez, "Enhanced thermal energy supply via central solar heating plants with seasonal storage: A multi-objective optimization approach," Appl. Energy, vol. 181, pp. 549-561, 2016.

[22] L. Guerreiro, D. Canavarro, and M. Collares Pereira, "Efficiency improvement and potential LCOE reduction with an LFR-XX SMS plant with storage,” Energy Procedia, vol. 69, pp. 868-878, 2015.

[23] K. Sartor, S. Quoilin, and P. Dewallef, "Simulation and optimization of a CHP biomass plant and district heating network," Appl. Energy, vol. 130, pp. 474-483, 2014.

[24] Drake landing solar community, "Drake landing solar community," http://www.dlsc.ca/, 2017. [Online]. Available: July.2017.

[25] S. Furbo, J. Fan, B. Perers, W. Kong, D. Trier, and N. From, “Testing, development and demonstration of large scale solar district heating systems," Energy Procedia, vol. 70, pp. 568-573, 2015.

[26] PlanEnergi, “planenergi," http://planenergi.eu/activities/fjernvarme/solar-heating/, 2017. [Online]. Available: 2017.

[27] Z. Liu, H. Li, K. Liu, H. Yu, and K. Cheng, "Design of high-performance water-in-glass evacuated tube solar water heaters by a high-throughput screening based on machine learning: A combined modeling and experimental study,” Sol. Energy, vol. 142, pp. 61-67, Jan. 2017.

[28] S. Kalogirou, "The potential of solar industrial process heat applications," Appl. Energy, vol. 76, no. 4, pp. 337-361, 2003.

[29] M. Biencinto, L. Gonzålez, and L. Valenzuela, "A quasi-dynamic simulation model for direct steam 
generation in parabolic troughs using TRNSYS," Appl. Energy, vol. 161, pp. 133-142, 2016.

[30] R. Leiva-Illanes, R. Escobar, J. M. Cardemil, and D.-C. Alarcón-Padilla, “Thermoeconomic assessment of a solar polygeneration plant for electricity, water, cooling and heating in high direct normal irradiation conditions," Energy Convers. Manag., vol. 151, pp. 538-552, Nov. 2017.

[31] R. Silva, M. Perez, and A. Fernandez-Garcia, "Modeling and co-simulation of a parabolic trough solar plant for industrial process heat," Appl. Energy, vol. 106, pp. 287-300, 2013.

[32] D. Krueger, A. Heller, K. Hennecke, K. Duer, S. Energietechnik, D. Zentrum, and L. Höhe, "Parabolic trough collectors for district heating systems at high latitudes," in Proceedings of Eurosun, 2000.

[33] Aalborg CSP A/S, “Aalborg CSP,” http://www.aalborgcsp.com/, 2017. [Online]. Available: July.2017.

[34] B. Perers, S. Furbo, and J. Dragsted, "Thermal performance of concentrating tracking solar collectors," DTU.Report, vol. 292, no. August, 2013.

[35] B. Perers, S. Furbo, Z. Tian, J. Egelwisse, F. Bava, and J. Fan, "Tårs $10000 \mathrm{~m}^{2}$ CSP + flat plate solar collector plant - cost-performance optimization of the design,” Energy Procedia, vol. 91, pp. 312-316, 2016.

[36] Z. Tian, B. Perers, S. Furbo, and J. Fan, "Annual measured and simulated thermal performance analysis of a hybrid solar district heating plant with flat plate collectors and parabolic trough collectors in series," Appl. Energy, vol. 205, pp. 417-427, 2017.

[37] D. Buoro, P. Pinamonti, and M. Reini, "Optimization of a distributed cogeneration system with solar district heating," Appl. Energy, vol. 124, pp. 298-308, 2014.

[38] Z.-Y. Zhao, Y.-L. Chen, and J. D. Thomson, "Levelized cost of energy modeling for concentrated solar power projects: A China study,” Energy, vol. 120, pp. 117-127, 2017. 
[39] Y. Louvet, S. Fischer, S. Furbo, F. Giovanetti, F. Mauthner, D. Mugnier, and D. Philippen, "LCOH for Solar Thermal Applications LCOH for Solar Thermal Applications Conventional reference system," http://task54.iea-shc.org/, 2017. [Online]. Available: July.2017.

[40] F. Mauthner and S. Herkel, "Classification and benchmarking of solar thermal systems in urban environments.TECHNOLOGY AND DEMONSTRATORS: Technical Report Subtask C - Part C1," http://task52.iea-shc.org/publications, 2016. [Online]. Available: Mar.2017.

[41] Werner Weiss, Monika Spörk-Dür, Franz Mauthner, Solar Heat Worldwide-Global Market Development and Trends in 2016-Detailed Market Figures 2015 (2017 version). http://www.ieashc.org/solar-heat-worldwide, 2017.

[42] Z. Tian, B. Perers, S. Furbo, and J. Fan, "Analysis and validation of a quasi-dynamic model for a solar collector field with flat plate collectors and parabolic trough collectors in series for district heating," Energy, vol. 142, pp. 130-138, 2018.

[43] TRNSYS, "TRNSYS 17-a TRaNsient SYstem Simulation program -Volume 4 Mathematical Reference," http://web.mit.edu/parmstr/Public/TRNSYS/04-MathematicalReference.pdf. [Online]. Available: June 2017.

[44] Y. Louvet, S. Fischer, S. Furbo, F. Giovannetti, F. Mauthner, and D. Mugnier, "Entwicklung eines Verfahrens für die Wirtschaftlichkeitsbe- rechnung solarthermischer Anlagen : die LCOH Methode," in OTTI conference (In German), 2017.

[45] M. J. Baez and T. L. Martinez, "Technical Report on the Elaboration of a Cost Estimation Methodology," http://www.front-rhc.eu/wp-content/uploads/2014/11/FROnT_D3.1_elaboration-of-acost-estimation-methodology_2015.07.22.pdf, pp. 1-28, 2016.

[46] J. Egelwisse, "Solar heating plants based on CSP and FP collectors," DTU Master Thesis, 2015.

[47] F. Bava, S. Furbo, and B. Perers, "Simulation of a Solar Collector Array Consisting of two Types of 

2015.

583 [48] Arcon-Sunmark, “Arcon-Sunmark A/S," http://arcon-sunmark.com/products. [Online]. Available: Mar.2017.

[49] J. Dragsted and S. Furbo, "Solar radiation and thermal performance of solar collectors for Denmark," DTU Rep., vol. 275, 2012.

[50] D. D. Nation, P. J. Heggs, and D. W. Dixon-Hardy, "Modelling and simulation of a novel electrical energy storage (EES) receiver for solar parabolic trough collector (PTC) power plants," Appl. Energy, vol. 195, pp. 950-973, Jun. 2017.

590

[51] A. Fernández-García, E. Zarza, L. Valenzuela, and M. Pérez, "Parabolic-trough solar collectors and 591 their applications," Renew. Sustain. Energy Rev., vol. 14, no. 7, pp. 1695-1721, Sep. 2010. 